\title{
Retrieval of wulfenite from the cryolite deposit, Ivigtut, South Greenland
}

\author{
ERIK S. LEONARDSEN, HANS PAULY, OLE V. PETERSEN AND JøRN G. RøNSBO
}

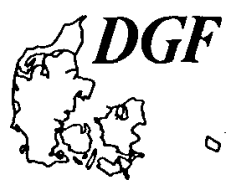

Leonardsen, E. S., Pauly, H., Petersen, O. V. and Rønsbo, J. G.: Retrieval of wulfenite from the cryolite deposit, Ivigtut, South Greenland. Bull. geol. Soc. Denmark, vol. 29, pp. 145-150, Copenhagen, January 19th, 1981. https://doi.org/10.37570/bgsd-1980-29-09

\begin{abstract}
Wulfenite from Ivigtut was mentioned by Gordon in 1939. Identification was based on goniometric measurements for which reason Bøggild in 1953 noted that the data might also fit those of stolzite.

New finds of similar crystals were made in 1978 and again in 1979 in thomsenolite parageneses different from the one described by Gordon.

$X$-ray and electron microprobe determinations proved the crystals to be wulfenite.

The secondary parageneses in which wulfenite was found are described. A search among other thomsenolite parageneses did not result in other finds of wulfenite. Wulfenite has a very limited distribution in the deposit. No definite source for lead and molybdenum could be indicated although minerals of these elements are frequently found in other parts of the deposit.

E. S. Leonardsen, Institute of Mineralogy, University of Copenhagen, Øster Voldgade 5-7, 1350 Copenhagen K., Denmark.

H. Pauly, Mineralogical Institute, Technical University of Denmark, building 204, 2800 Lyngby, Denmark. O. V. Petersen, Geological Museum, University of Copenhagen, Øster Voldgade 5-7, 1350 Copenhagen K., Denmark.

J. G. Rønsbo, Institute of Mineralogy, University of Copenhagen, Øster Voldgade 5-7, 1350 Copenhagen
\end{abstract} K., Denmark.

Wulfenite from Ivigtut was first mentioned by Gordon (1939). His entire material consisted of two greyish-yellow, $1 \mathrm{~mm}$ crystals with an adamantine lustre perched upon thomsenolite, with occasional ralstonite, found in a cavernous mass of cryolite and fluorite. The identification was based exclusively on the $\{001\} \Lambda\{111\}$ and $\{001\} \Lambda\{011\}$ as determined on the goniometer; besides $\{111\}$ and $\{011\}$ Gordon also identified $\{221\}$ and $\{340\}$. Fig. 1a shows the drawing of the wulfenite crystals as presented by Gordon; $\{001\}$ to be seen on Gordons figure has been omitted. Modern indices of the forms identified by Gordon are given below.

In his Mineralogy of Greenland, Boggild (1953) raises some doubt as to whether wulfenite does occur in Ivigtut by pointing out that the measurements reported by Gordon agree well with the values of wulfenite, but might also, to a certain extent, be in accordance with stolzite ( $\mathrm{PbWO}_{4}$ ).

In 1978 one of the authors (HP) found wulfenite as half millimetre long double pyramids, faintly limonite stained crystals sticking to thomsenolite crystals a few millimetres in size (see fig.
2). The identification was based on the optical properties, specific gravity, their X-ray powder pattern and their appearance, which recall Gordon's description of wulfenite crystals from a thomsenolite paragenesis.

At the end of 1979, the Geological Museum in Copenhagen received for identification from a private collector, Mrs. D. Ingeman Rasmussen, 5 specimens, all with one or more small crystals of what seemed to be wulfenite. These samples could be related to a specific part of the cryolite deposit and it was decided to settle finally the problem as to whether wulfenite or stolzite occurs in Ivigtut. Examination of similar samples collected in the cryolite mine (by HP) in 1960-62 has brought to light a few specimens with crystals of wulfenite.

Habit, X-ray diffraction and chemistry

The crystals of the present investigation are generally smaller than the two found by Gordon, 0.5 $\mathrm{mm}$ at a maximum. Due to limonite staining, the true colour and the degree of transparency of the wulfenite crystals in the type of material found 2 years ago are difficult to determine, but they ap- 

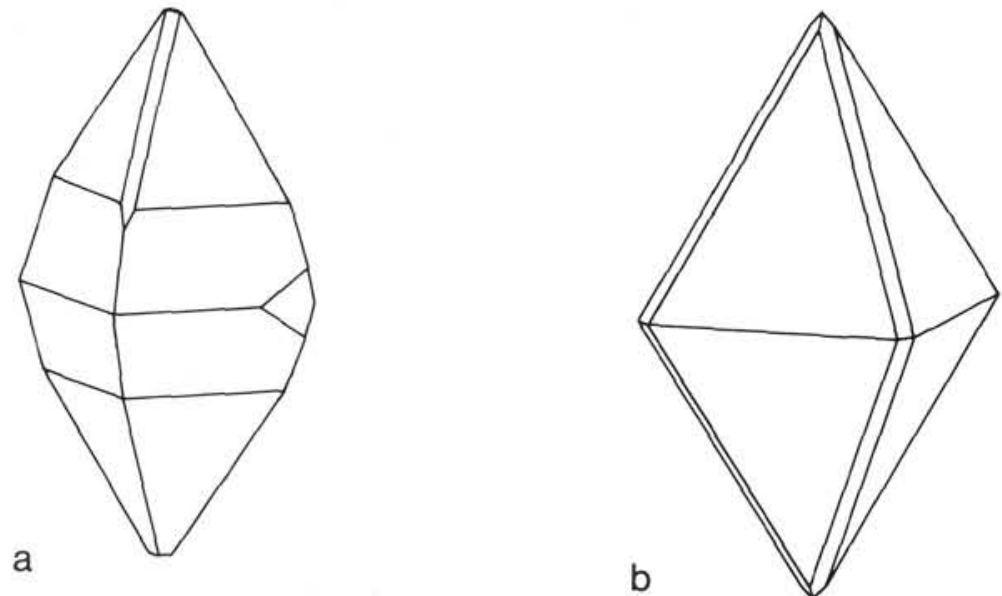

Fig. 1a: Drawing of the wulfenite crystals, as presented in Gordon (1939). b: Drawing of the wulfenite crystals from the present investigation.

pear to differ from both those of Gordon and those brought to the Geological Museum recently by being whitish and untransparent. The wulfenite crystals of the type of material brought in recently are smoky coloured, partly with a greenish tint, transparent and have an adamantine lustre, thus resembling rather closely those described by Gordon.

The crystals of the present investigations, although habitually similar to Gordon's crystals,

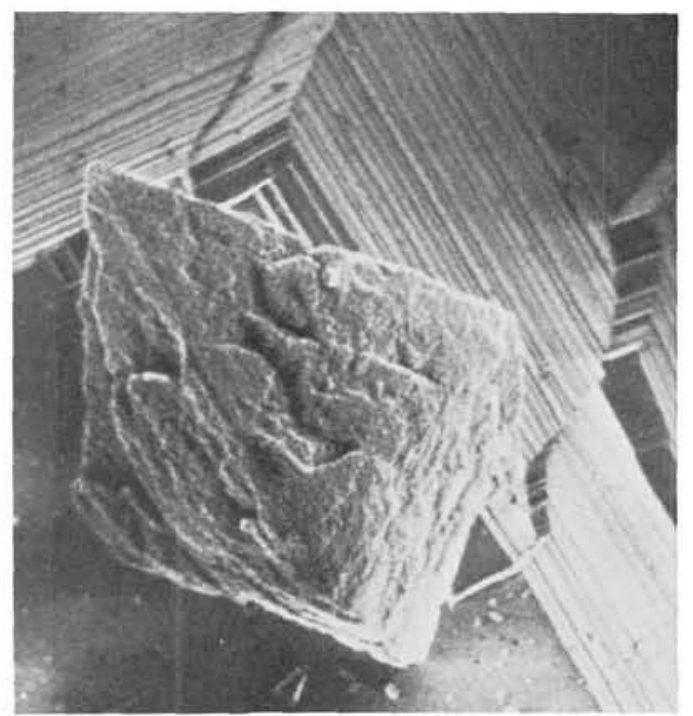

Fig. 2. Limonite stained crystal of wulfenite on (001) of a thomsenolite crystal. Note the combination striation on $\{110\}$ of the thomsenolite. S.E.M. $\times 150$. show only four forms $\{101\},\{10 \overline{1}\},\{112\}$ and $\{11 \overline{2}\} ;\{101\}$ and $\{10 \overline{1}\}$ corresponding to Gordon's $\{111\}$ and $\{112\}$ and $\{11 \overline{2}\}$ to Gordon's $\{011\} .\{101\}$ and $\{10 \overline{1}\}$ dominate among the four forms. Fig. 1b shows a drawing of the wulfenite crystals of the present investigation. A single tiny, stained crystal further showed $\{100\}$, rather dominating. The additional forms observed by Gordon, $\{221\}$ and $\{340\},\{221\}$ corresponding to $\{201\}$ and $\{20 \overline{1}\}$ and $\{340\}$ corresponding to

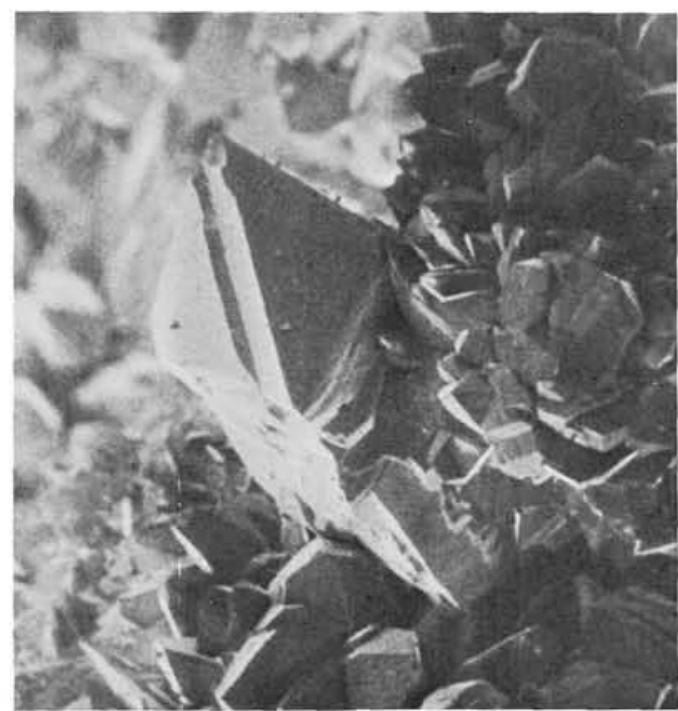

Fig. 3. Crystal of wulfenite, from the prosopite material, showing parallel growth. S.E.M. $\times 150$. 
$\{710\}$ as well as $\{001\}$ corresponding to $\{001\}$ and $\{00 \overline{1}\}$, are absent. Several cases of parallel growth (see fig 3 ) and one hopper crystal (see fig. 5) have been found.

Powder pattern of one single crystal (c. $0.5 \mathrm{~m}$ $\mathrm{m}$ long) was obtained with a Gandolfi camera, diam. $114.6 \mathrm{~mm}$, Gandolfi (1967), using $\mathrm{Cu}$ radiation and $\mathrm{Ni}$ filter. Least squares refinement of 8 backreflection lines $\left(2 \theta<127.5^{\circ}, 171^{\circ}>\right)$, gave the following unit cell:

$$
\begin{aligned}
& \mathrm{a}_{0}=5.4344 \text { (7) } \AA, \mathrm{c}_{0}=12.109 \text { (2) } \AA, \mathrm{V}= \\
& 357.61 \AA^{3}
\end{aligned}
$$

which is in close agreement with values reported elsewhere for wulfenite.

Electron microprobe analysis of one of each of the two different types of crystals showed that the composition of both is very close to the ideal composition of wulfenite. Besides lead and molybdenum, only minor amounts of calcium $(0.18-0.23 \% \mathrm{CaO})$ and tungsten have been detected. The tungsten content varies from less than 0.05 up to $0.95 \% \mathrm{WO}_{3}$ in the investigated grains. The rise in tungsten is accompanied by a corresponding fall in the molybdenum content.

\section{Paragenesis}

Gordon's observation that his wulfenite crystal occurs in "a cavernous mass of cryolite and fluorite" is important because it clearly relates his sample to fluorite-cryolite as opposed to the siderite-cryolite representing the main mass in the deposit (see Pauly 1960 and Karup-Møller \& Pauly 1979 for details).

The thomsenolite described by Gordon as tabular crystals is, in spite of Gordon's remark, to be regarded as rare in Ivigtut according to the experience of the mineralogists who worked for Kryolitselskabet Øresund A/S (HP was attached to the company during the last 15 years of the existence of the mine).

Gordon described ralstonite crystals as octahedra partly truncated by small cube faces. This indicates a low content of $\mathrm{Na}-\mathrm{Mg}$ in the mineral (Pauly 1965).

The first rediscovery of wulfenite crystals was made in samples consisting of thomsenolite with scattered ralstonite crystals and an occasional pachnolite crystal. The thomsenolite crystals of these samples (see fig. 4) are unusual because

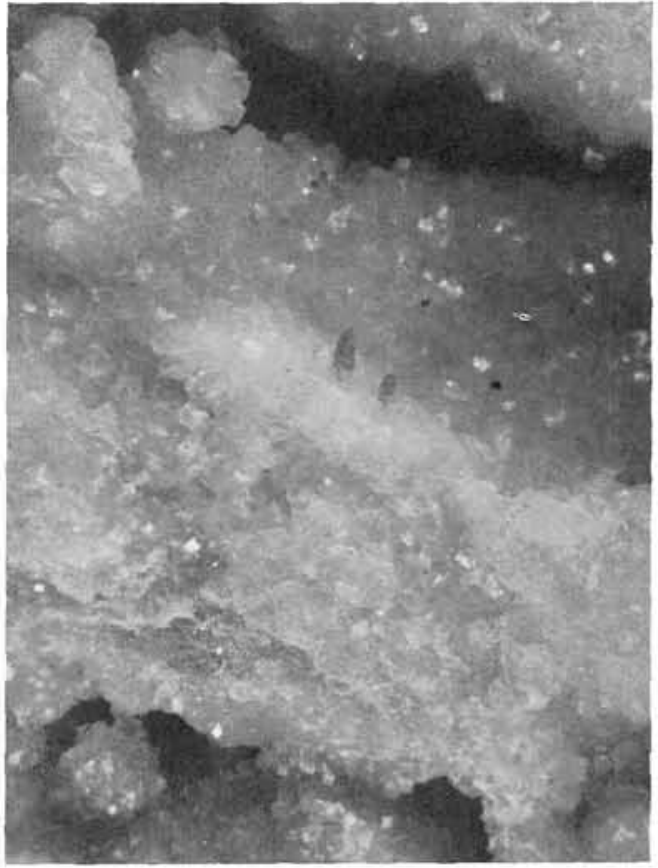

Fig. 4. Aggregate of cube-like crystals of thomsenolite, $\times 1.5$.

they appear as short prisms, 1-2 mm high, terminated by the base which is a square having an edge approximately $1 \mathrm{~mm}$ long. Superficially these crystals look like cubes. On closer inspection one notes the combination striation on the prism faces (see fig. 2) whereas the bases appear slightly inwards curved and composed of several subareas differing a little from each other in orientation. The aggregates of these thomsenolite crystals look like rock candy; the dense parts, up to $1 \mathrm{~cm}$ thick, enclose numerous small and large voids (see fig. 4). In one case such a void was seen to continue for about $20 \mathrm{~cm}$ with a width of up to $5 \mathrm{~cm}$. In this particular sample wulfenite crystals are found only at one end of the sample and only 3 in number. In an $8 \mathrm{~cm}$ long sample about 30 wulfenite crystals are observed. About a dozen smaller samples were found to contain one or two wulfenite crystals. All these wulfenite crystals were limonite stained.

Ralstonite occurs in the shape of cubes truncated by small octahedral faces, indicating high proportions of $\mathrm{Na}-\mathrm{Mg}$ in the mineral (Pauly 1965).

A few slender prismatic crystals of pachnolite have also been observed in these specimens. 


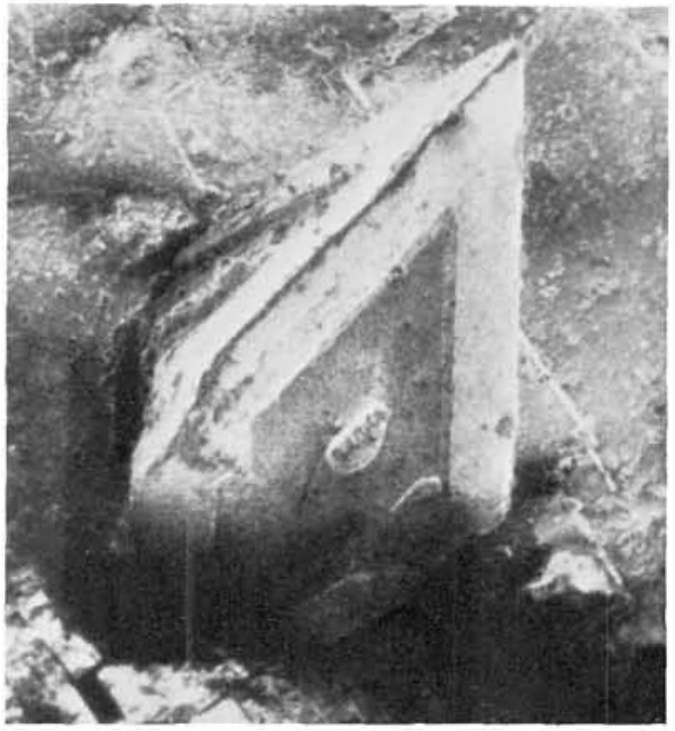

Fig. 5. Hopper crystal of wulfenite. S.E.M. $\times 150$.

Light greenish elongated patches can be found here and there in the massive parts of the aggregates. They consist of thomsenolite crystals enclosing som fine-grained greenish mica. As fluorite-cryolite in Ivigtut is characterized by the presence of a fine-grained $\mathrm{K}$-mica, it is supposed that these thomsenolite aggregates represent a specific type probably developed at the expense of cryolite from fluorite-cryolite.

Among the wulfenite crystals observed in this material was the one depicted in fig. 5 . It is 0.5 $\mathrm{mm}$ in length. As can be seen from the photo it is developed as a hopper crystal, obviously indicating rapid growth as compared with the other fully developed wulfenite crystals.

The second rediscovery of wulfenite crystals was made in samples characterized by bluish, dense masses of the mineral prosopite. Thomsenolite, white to only slightly limonite stained dominates these specimens. All over the samples are voids of widely varying sizes mostly lined with thomsenolite crystals of the usual type, i.e. long tapering prismatic crystals usually terminated by the base and more or less clearly developed dome faces. Pachnolite may be present and ralstonite can always be found. Cavities in dense prosopite are found to carry tiny sheaf-like bundles of prosopite crystals.

Most observations indicate that the ralstonite crystals are cubes truncated by small octahedral faces, but in one case a fairly well developed octahedron was observed, see later.

As opposed to the wulfenite crystals described above, those found in the prosopite samples are unstained thus revealing the high lustre of the mineral. The crystals are, as the former, developed as double pyramids.

The occurrence of prosopite in the cryolite deposit is mentioned in Bøggild (1953). The light bluish-grey aggregates of prosopite were only found in the south-west corner of the quarry $66 \mathrm{~m}$ below sea level. This deep level was approached in 1960 and blastings exposed the prosopite mass late in the summer of 1962. An appropriate amount of samples was secured (by HP) for future studies. These samples belong to the lower part of the fluorite-cryolite.

The samples in which wulfenite was found clearly belong to this type of prosopite. As it has only been found in the above-mentioned place in the deposit, it is beyond doubt that they also had their origin here.

The collection of samples secured in 1962 was therefore searched in order to see if further wulfenite bearing specimens could be found. So far only two more samples have been found. They showed the wulfenite in quite the same way as the samples in the collections of D. Ingeman Rasmussen, but in one sample wulfenite was sticking to the edge of a well developed octahedron of water clear ralstonite. In all the other observed cases the crystals of wulfenite cling to the crystal faces of thomsenolite.

Among the prosopite samples examined for possible wulfenite crystals some were found to carry light coloured greenish sphalerite in rounded grains of sizes similar to the wulfenite crystals. In a few other samples were found sulphide aggregates consisting of dark sphalerite and a little chalcopyrite. The latter also occurs as droplets in the sphalerite in an emulsion texture, and sphalerite occurs as starshaped skeletal crystals in the chalcopyrite. These features are characteristic of the occurrence of these minerals in the siderite-cryolite (Pauly 1960).

\section{Wulfenite and secondary parageneses in Ivigtut}

The peculiar position of the wulfenite crystals sticking onto the crystal faces of thomsenolite, and especially the wulfenite crystal attached to an edge of an octahedron of ralstonite clearly de- 
monstrate their late formation within this paragenesis of secondary minerals in the cryolite deposit. The limonite coating represents the only mineral formation later than the wulfenite.

The common aggregates of thomsenolite pachnolite - ralstonite certainly formed through dissolution of cryolite simultaneously followed by the precipitation of thomsenolite. This is nicely brought out by numerous samples of the type depicted in Bøggild (1953, fig. 12) showing thomsenolite replacing cryolite, perfectly modelling the lamellae systems originally representing twin lamellae in the cryolite.

In most cases the following paragenetic sequence can be established for the secondary minerals:

cryolite $\rightarrow$ thomsenolite + pachnolite + ralstonite

In terms of chemical components it is:

$\mathrm{Na}_{3} \mathrm{AlF}_{6}+\left(\mathrm{Ca}^{++}\right)+\left(\mathrm{Mg}^{++}\right) \rightarrow \mathrm{NaCaAl}(\mathrm{F}$, $\mathrm{OH})_{6} \mathrm{H}_{2} \mathrm{O}+\mathrm{Na}_{\mathrm{x}} \mathrm{Mg}_{\mathrm{x}} \mathrm{Al}_{2-\mathrm{x}}(\mathrm{F}, \mathrm{OH})_{6} \mathrm{H}_{2} \mathrm{O}$

The presence of quite unaltered siderite in compact aggregates of thomsenolite indicates that this mineral was not attacked by the solutions. The dissolution of siderite and precipitation of limonite belong to a later series of processes.

It is difficult to point to sources outside the deposit which could give rise to solutions precipitating the thomsenolite-ralstonite assemblages. Whereas the solutions decomposing siderite and leaving limonite might well be of meteoric origin, the former are more likely juvenile in origin.

Such an origin is clearly attributable to the solutions which gave rise to another secondary paragenesis in which jarlite occurs together with thomsenolite in cavities in columnar aggregates (Bøgvad 1933). The aggregates contain barytes besides other minerals. They occurred as isolated irregular masses within the fluorite cryolite. The solutions involved in these formations were clearly much more complex in composition than those giving rise to the common thomsenolite paragenesis.

The occurrence of the prosopite-thomsenolite paragenesis in the deep SW part of the deposit should likewise be regarded as a product of late fluids reacting within the fluorite cryolite mass. Compared to the solutions forming the common thomsenolite paragenesis, these fluids were obviously rather rich in calcium giving rise to the formation of prosopite, $\mathrm{CaAl}_{2}(\mathrm{~F}, \mathrm{OH})_{8}$, whereas the sodium content in the early stage, where this mineral was formed, seemingly played a minor role. Thomsenolite, formed late in this paragenesis, indicates a shift in the $\mathrm{Na:Ca}$ proportions. The relations are more complicated, however, and need further studies. The presence of ralstonite points to a certain content of magnesium in the solutions; the dominating cubic habit of the crystals goes together with high $\mathrm{Na}-\mathrm{Mg}$ proportions in the mineral, but the presence of a distinctly octahedral crystal is indicative of the formation also of ralstonite with low $\mathrm{Na}-\mathrm{Mg}$ content (Pauly 1965).

Still another type of secondary product in the cryolite deposit should be mentioned: the stalagtitic minerals described by Bøggild (1912 and 1913); they include fluorite among the other secondary minerals.

Gearksutite, $\mathrm{CaAl}(\mathrm{F}, \mathrm{OH})_{5} \mathrm{H}_{2} \mathrm{O}$, belongs to several of these parageneses of secondary minerals. As cavity fillings, this extremely fine-grained earth like material certainly belongs to a late stage, but its position is not yet fully cleared up. It is mentioned here in order to show the nature of the chemical elements involved in the formation of secondary minerals in the cryolite deposit. Finally it is also worth mentioning that the famous cryolite crystals from Ivigtut represent secondary crystallizations on fissures and in cavities in the cryolite and thus give evidence about solutions so singularly loaded with dissolved matter that crystals of just this one mineral were formed. Later coatings with limonite are products of a new series of processes involving the fissures filled with cryolite crystals.

Despite careful search wulfenite has not been detected in any other type of secondary mineral parageneses from Ivigtut than those described in the preceding section on paragenesis. To this should be added that Gordon's article was known to the mineralogists working at the cryolite mine in Ivigtut and at the dressing plant in Copenhagen. In spite of this, wulfenite did not turn up before 1978 when registration of the stores of secondary minerals from the mine was undertaken. 


\section{Discussion}

Among the various parageneses the wulfenite is only present in some, more or less clearly belonging to the fluorite-cryolite. The samples with blue prosopite clearly indicate this and in the other samples the accompanying minerals strongly suggest a similar position for these samples. After the formation of wulfenite only limonite precipitated. It seems fair to assume that wulfenite precipitated from the solutions giving rise to thomsenolite and the other secondary fluorides. However, the source of the elements constituting the mineral - lead and molybdenum - is not evident.

Karup-Møller and Pauly (1979) gave a survey of the distribution of opaque minerals from the cryolite deposit. It was stated that molybdenite has not been observed in fluorite-cryolite. It is present as a characteristic accessory mineral in the pegmatite overlying the deposit and in the greisen rocks enclosing parts of the cryolite mass. It is also present, although in very small amounts, in the sulphide aggregates in the siderite-cryolite.

Lead in the form of galena and a number of sulphosalts has been found also in fluorite-cryolite but in very restricted amounts and at very few locations within the mine. These locations have no obvious connection with the prosopite locality.

The sphalerite chalcopyrite aggregates enclosed in some prosopite samples seem to represent relicts of decomposed siderite-cryolite. The elements lead and molybdenum might then have been derived from the sulphides of these elements which are known to occur in the siderite cryolite. The aggregates in the prosopite, however, showed no signs of corrosion or chemical break-down. The origin of the elements constituting the mineral wulfenite may be unrelated to such specific parageneses, and should perhaps rather be sought in stray solutions wandering through the deposit.

Acknowledgements. This investigation was inspired by the fine specimens Mrs. D. Ingeman Rasmussen kindly placed at our disposal; for this we offer our warm thanks. Mr. M. Hansen is thanked for the scanning electron micrographs. Dr. J. Bailey kindly read the manuscript and the English language of the article was much improved thanks to his suggestions. The Danish Natural Science Research Council provided the microprobe facilities at the University of Copenhagen.

\section{Dansk sammendrag}

I 1939 beskrev Gordon to små krystaller af wulfenit fra Ivigtut. Identifikationen var udelukkende baseret på goniometriske målinger og Bøggild (1953) rejste derfor med rette tvivl om identifikationen; der kunne foreligge stolzit.

11978 fandtes ved gennemgangen af en større samling thomsenolit-prøver flere lignende $0.5 \mathrm{~mm}$ store krystaller. I 1979 bragte fru D. I. Rasmussen flere thomsenolit-prosopit-prøver til museet for at få identificeret nogle små krystaller siddende på thomsenolit. Den foreløbige undersøgelse syntes at vise, at der forelå wulfenit. Røntgenundersøgelse og mikrosondeundersøgelse af prøverne fra både 1978 og 1979 viste samstemmende, at krystallerne var wulfenit.

Wulfenit er ikke fundet $i$ andet materiale end de to typer, der er repræsenteret i prøverne fra 1978 og 1979, begge knyttet til flusspat-kryoliten.

Wulfeniten sidder på thomsenolit og $\mathrm{i}$ et enkelt tilfælde $\mathrm{p} \AA$ kanten af en oktaedrisk krystal af ralstonit, wulfeniten er sâledes dannet senere end disse mineraler som det sidste produkt af de reaktioner, hvorved thomsenolit etc. blev dannet. Det er vanskeligt at pege på en bestemt oprindelse for det bly og molybdæn, der udgør mineralet. Der synes ikke at være nogen direkte forbindelse mellem disse mineraliseringer og de steder $i$ forekomsten, hvor blyglans og molybdænglans forekommer.

\section{References}

Bøggild, O. B. 1912: De stalagtitiske Mineraler fra Ivigtut. Meddr Grønland, L: 177-185.

Bøggild, O. B. 1913: Die stalagtitischen Mineralien von Ivigtut. Z. Kristallographie LI, 6: 614-623.

Bøggild, O. B. 1953: The Mineralogy of Greenland. Meddr Gronland 149(3): 1-442.

Bøgvad, R. 1933: New Minerals from Ivigtut, Southwest Greenland. Meddr Gronland 119(7): 1-11.

Gandolfi, G. 1967: Discussion upon methods to obtain X-ray "powder patterns" from a single crystal. Miner. Petr. Acta 13: $67-74$.

Gordon, S. G. 1939: Wulfenite, ralstonite and thomsenolite from Ivigtut, Greenland. Acad. Nat. Sci. Philad., Notulae Naturae, 11: 1-2.

Karup-Møller, S. \& Pauly, H. 1979: Galena and associated ore minerals from the cryolite at Ivigtut, South Greenland. Meddr Gronland, Geoscience 2: 1-25.

Pauly, H. 1960: Paragenetic relations in the main cryolite ore of Ivigtut, South Greenland. Neues J. Miner. Abh. 94, Festband Ramdohr, 121-139.

Pauly, H. 1965: Ralstonite from Ivigtut, South Greenland. Amer. Miner., 50: 1851-1864. 